DOI 10.32370/IA_2020_01_10

\title{
Missed Opportunities for Previous Examinations under the Current Criminal, Civil and Criminal Procedure Codes of Ukraine
}

\begin{abstract}
Atamanchuk Volodymyr
PhD of Juridical Sciences, Chief of Department of Forensic Support and Forensic Expertise of the National Academy of Internal Affairs, Kiev, Ukraine ORCID ID 0000-0002-1464-7871 atamanchykvlad@ukr.net

\section{Pavlovska Nataliia}

PhD of Juridical Sciences, Associate Professor, Professor of Department of Civil Law and Process of the National Academy of Internal Affairs, Kiev, Ukraine ORCID ID 0000-0003-3311-0364 wwwpav@gmail.com
\end{abstract}

\section{Kulyk Maryna}

PhD of Juridical Sciences, Associate Professor of Forensic Support and Forensic Expertise of the National Academy of Internal Affairs, Kiev, Ukraine ORCID ID 0000-0003-1373-6749 coolss777@ukr.net

\section{Symchuk Anatolii}

Senior Teacher of Forensic Support and Forensic Expertise of the National Academy of Internal Affairs, Kiev, Ukraine ORCID ID 0000-0002-8663-8210 symchukas@gmail.com

\section{Filipova Natalia}

Asistant of the Departament of Law of Prydunai Branch of Private Jointstock Company «Higher Educational Institution of Interregional Academy of Personnel Management», Izmail, Ukraine ORCID ID 0000-0001-7132-8343 filinatalja2310@ gmail.com

\footnotetext{
Abstract

The article presents the author's viewpoint on the assessment of positive and negative aspects beyond the procedural status of the expert's opinion, as well as current prospects for the implementation of the previous positive experience.

The key purpose, for which the conduct of examinations and provision of expert opinions was intended, was to implement the principle of rapid (prompt) delivery of evidentiary information for the purpose of detection
} 
and investigation of crimes. Most often, the conduct of examinations and provision of opinions by experts were ordered in the areas of forensic examination, one of which included forensic weapon analysis.

Keywords: investigator, examinations, expert's opinion, forensic weapon analysis.

Introduction Naturally, the sooner the investigator (operative officer) received most of the useful information on the case, the higher the chances were that the crime would be solved and the perpetrator exposed. Therefore, these examinations were largely conducted at the initial phase of the investigation, at a stage of initiation of a criminal case or (before the start of the criminal process) at a stage of operative and investigative activities focused on identifying the crime, i.e., when the essential evidentiary information reflected in the physical traces of the crime had to be obtained as soon as possible, while no conditions, possibilities or legal prerequisites existed for the conduct of a forensic examination.

The nature of any performed forensic weapon analysis, finalised in such a document as an expert opinion, was both procedural and non-procedural. Its existence or absence in the legal framework depended on the stage of the process at which it was ordered and on the agency (person) initiating such analysis [1].

At present, certain challenges arise in determining the items of crimes, when categorised under Articles 262-264, 410 of the Criminal Code of Ukraine.

The provisions of Articles 262-264, 410 of the Criminal Code of Ukraine (the "CCU") criminalise, in particular, illegal actions related to dealing with firearms, ammunition, explosive devices (items of crime) that, for the purpose of categorising certain items as items of crime under these articles are analysed during forensic examinations of weapons and explosives.

Thus, Article 263 of the CCU defines two types of weapons: firearms (other than smooth-bore weapons) and cold weapons, although no definition of the types of ammunition or explosive devices is given.

The Resolution No. 3 of the Plenary Assembly of the Supreme Court of Ukraine "On judicial practice in the cases of theft and other illegal handling of weapons, ammunition, explosives, explosive devices or radioactive materials" dated 26/04/2002 clarifies that:

firearms shall mean all types of combat, sports, and rifled hunting weapons, both commercially manufactured and home-made or converted, which use the pressure force of gases formed by combustion of an explosive substance (gunpowder or other special 
combustible mixtures) to fire a shot;

ammunition shall mean cartridges for rifled firearms of various calibres, artillery shells, bombs, mines, grenades, warheads of missiles and torpedoes and other assemblies, equipped with explosives and intended for firing firearms or making an explosion;

explosive devices shall mean home-made or industrially manufactured disposable products, specially prepared and, under certain circumstances, capable, through the use of chemical, heat, electrical energy or physical action (explosion, impact), of generating effects - i.e., to cause death, bodily injury or significant material damage - through the release, dispersion or exposure to toxic chemicals, biological agents, toxins, radiation, radioactive materials or other similar substances.

In addition to the said items of crime, experts nowadays also examine disposable and reusable rocket launchers, artillery systems (guns and mortars), flamethrowers, portable and mobile (combat vehicles) anti-tank missile and anti-aircraft missile systems, their ammunition and missiles that, at least, are not defined by the above regulations. Electroshock devices with certain characteristics remain beyond the categorisation of weapons [2].

Given the above, forensic categorisation of weapons requires more precise definitions, based on the expert practice and provisions of regulatory documents that govern it, first of all, the Instructions on ordering and conducting forensic examination and expert analysis, and the Methodological guidelines on preparing and ordering forensic examination and expert analysis, approved by the Order No.53/5 of the Ministry of Justice of Ukraine dated 08/10/1998, as well as similar regulatory documents from the expert services of the Ministry of Internal Affairs of Ukraine (the "MIA") and the Security Service of Ukraine (the "SSU").

It is thus proposed that the forensic categorisation of weapons and their ammunition be updated to read as follows: cold weapons; non-kinetic weapons (electroshock devices and nonrocket flamethrowers); small arms (industrially manufactured or home-made) and their ammunition; reusable grenade launchers and flamethrowers, rounds (grenades) for them; disposable grenade launchers and flamethrowers; artillery pieces (guns, howitzers, mortars) and their ammunition; rocket weapons (rocket systems (RS), multiple launch rocket systems (MLRS), portable and mobile anti-tank missile systems (ATMS) and anti-aircraft missile systems (AAMS), their ammunition and missiles.

Based on the weapon categorisation, items of the expert examination of weapons and 
explosives have been defined, i.e., "Items of analysis in the expert examination of weapons."

It is suggested that the current list (all types of combat, sports, rifled hunting weapons), with regard to new items, be revised to read as follows: 1. Small arms (industrially manufactured or home-made) and their ammunition; 2. Reusable grenade launchers and flamethrowers; 3. Cold weapons; 4. Non-kinetic weapons (electroshock devices and nonrocket flamethrowers); 5. Artillery pieces (guns, howitzers, mortars); 6. Rocket and missile weapons (rocket systems (RS), multiple launch rocket systems (MLRS), anti-tank missile systems (ATMS), mobile and portable anti-aircraft missile systems (AAMS) and modifications thereof).

\section{Items of analysis in the expert examination of explosives}

The current list (artillery shells, bombs, mines, grenades, warheads of missiles and torpedoes and other assemblies, equipped with explosives and intended for firing firearms or making an explosion) be amended to include the following: grenades (rounds) for reusable grenade launchers and flamethrowers; disposable grenade launchers and flamethrowers, torpedoes, missiles.

Items of analysis in the expert examination of weapons and explosives may also include fragments of the above-listed items of crime, which have remained after their use.

Therefore, to ensure adequate regulatory support for circulation of weapons in this country, laws must be drafted and adopted to govern the circulation of military and specialpurpose weapons, as well as the circulation of civilian weapons.

Furthermore, the list of expert specialities in the field of expert examination of weapons has been updated: "Expert examination of weapons."

1. Analysis of small arms and their ammunition, reusable grenade launchers and flamethrowers (Speciality 3.1).

2. Analysis of traces of small arms and their ammunition, reusable grenade launchers and flamethrowers, traces and situational circumstances of their application (Speciality 3.2).

3. Analysis of cold weapons (Speciality 3.3).

4. Analysis of non-kinetic weapons, traces and situational circumstances of their application (Speciality 3.4).

5. Analysis of artillery pieces, traces and situational circumstances of their application (Speciality 3.5). 
6. Analysis of rocket and missile weapons, traces and situational circumstances of their application (Speciality 3.6).

Further efforts to improve statutory instruments that govern expert examination of weapons and explosives would require a revision of the methodologies for analysis of those objects that may constitute items of crimes under Articles 262-264, 410 of the Criminal Code of Ukraine, along with subsequent refinement of these methodologies.

Therefore, during the conduct of (at the stage of conducting) operative and investigative activities (the stage where elements of crime are identified), an analysis would be ordered at the request of operative units $(\S \S 4.1-4.6$ of the Guidance on the operation of the forensic expert service of the Ministry of Internal Affairs of Ukraine); this analysis was not regarded as a procedural one, since it was taking place beyond the framework of a criminal process (conduct of investigation).

Any analysis was regarded to have been regulated procedurally, if ordered after the criminal case had been initiated - at a stage of preliminary or judicial investigation, on the basis of attorneys' applications (Article 6 of the Law of Ukraine "On the Bar", Article 48 of the "previous" Criminal Procedure Code of Ukraine (the "CPCU")), at the request of customs authorities, notaries $(\S 3$ of the Instructions on ordering and conducting forensic examinations, as approved by the Order of the Ministry of Justice of Ukraine No. 53/5 dated 08/10/99), following the applications filed by organisations and members of the public (the Law of Ukraine "On Forensic Examination”).

From a legal viewpoint, the most contentious issues of non-procedural analysis have been due to the following: performing the analysis of items and substances that could acquire the status of evidence prior to expert examination as a procedural action; performing the analysis outside the framework of criminal process, i.e., the impossibility for parties to the investigation to control the material evidence; a unique nature of the analysis of certain items, in particular, in the field of "forensic weaponology" involving home-made weapons and homemade cartridges that could only be recognised as firearms or ammunition following a forensic experiment (experimental firing), which involved the expenditure (destruction) of a certain number of these items (the analysis would involve only those techniques that neither alter the appearance or properties of the analysed items nor result in their loss or preclude subsequent expert examination under $\S 5.3 .4$ of the Guidance. The experts conducting such an analysis 
followed the relevant advice that, where necessary, not all the analysed items should be used up, as another expert institution might be later charged with performing the analysis); "blanket" rejection of the expert's opinion as a source of evidence in criminal proceedings; the person conducting the analysis is granted the status of an expert whose written opinion lacks a written warning against giving a knowingly false opinion. A good example of this is the following situation: on the instructions from an investigator of the oblast prosecutor's office, a forensic analysis of a sawn-off shotgun was performed by an expert institution of the Ministry of Internal Affairs of Ukraine, finalised as an expert opinion. The sawn-off shotgun was found to be a firearm suitable for firing. It subsequently became necessary to file charges under Article 263 of the CCU in addition to those that have already been filed. Due to the fact that the expert opinion could not be used as the basis for the indictment, the judge, upon submission from the prosecutor, issued a ruling to perform a forensic ballistic examination, albeit at another expert institution in the MIA system.

In this particular instance, the progress and outcomes of the examination should have been recorded, meaning that where the examination is not possible without the use of the techniques that change the appearance of the examined items, their initial state is to be additionally recorded and photographed, and a summary of the examination process is to be provided, containing references to the techniques and technical means applied, along with the description of the identified features and their assessment results. The nature of the changes and the amount of the materials used should also have been indicated. All this should have been attested by a signature of the person performing the examination. Taken together, these requirements would have allowed for the essential principle in the law of evidence, i.e., reliability (validity as an integrity of evidentiary properties of the investigated traces, and the reliability of the actual data obtained during their examination) to be maintained [3].

At the same time, any examination of physical sources of evidentiary information, which may subsequently acquire the status of physical evidence, should under no circumstances, in this author's opinion, be moved beyond the legal framework or conducted "covertly" outside legal formalities, without recording the progress and outcomes of such examination in legal (procedural) documents. Handling the sources of evidentiary information should at all times be open and recorded with the use of procedural means. The record must be complete, comprehensive and continuous, beginning with the identification of a physical item 
that has a probative value and ending with its examination. Otherwise, no guarantees could exist that the evidentiary properties of a seized item have remained intact and the item itself may represent a reliable source of information and means of finding the objective truth.

Thus, a contradictory nature of the expert opinion has been observed, with regard to the possibility of its expanded presentation and compliance with the principles of reliability and admissibility of physical evidence against the background of the preliminary examination performed outside the criminal process; accordingly, the expert opinion required reviewing, rather than revoking its status in the context of the criminal process in Ukraine.

Therefore, since those items that have the status of physical evidence or may acquire this status later are subjected to examination, any preliminary analysis of such items should not be performed covertly. This examination must be performed within the framework of legal formalities, thereby guaranteeing the reliability of the analysis, the validity of its conclusions, and the integrity of the investigated evidence. In this context, the experts' opinions should have been given the status of an evidentiary source. This could have been particularly pertinent to the properly registered items that had been sufficiently established procedurally and might have acquired the status of physical evidence, whose examination is unique and, at the same time, should be done fast. In this case, it is impractical, from a legal viewpoint and for reasons of saving the expert's and the investigator's time, efforts and resources, to perform, under a respective ruling, any complete "automatic" re-examination following a preliminary analysis that should be granted the appropriate legal status ("sources of physical evidence").

In view of the European standards of justice being introduced in this country, an urgent need exists for improvements to the administrative and legal principles of conducting a forensic examination, processing its results and for bringing them closer to European standards. This approach should ensure prompt handling of analysed items, while observing the principles of legality, reliability and objectivity. The prerequisite for transitioning to a simplified option for finalising the expert opinion is rooted in the common format of examining the sources of evidentiary information, which is determined by the commonality of the content and methods of examination, since the analysis methodology at the stage of preliminary examination is no different from the one used at the stage of expert examination. The simplified nature of a finalised expert opinion is manifested in the absence of an analysis section (description of the analysis process) in such an opinion. An expert opinion may be used in this form where a need 
exists for a fast and immediate examination, while the examination itself does not entail annihilation of the examined items with destructive methods. The expert must provide a descriptive section of the analysis at the request of the initiator of the forensic examination or the court (where not initiated by the court) [4].

This simplified option for drafting the expert opinion is also supported through implementation of a management system according to the requirements of the DSTU ISO/IEC 17025 standard.

Compliance with the DSTU ISO/IEC 17025 requirements enables the implementation of such key principles of the MIA expert service operation as continuous improvements in the quality of examinations, along with strict monitoring of the reliability of their outcomes.

The improved reliability of the studies is achieved by precise functioning of the personnel training and retraining system, application of advanced research techniques (methods), introduction of modern measuring devices and test equipment and their proper maintenance, observance of strict confidentiality, professional secrecy and the customers' rights of ownership.

Similar to any introduction, intended to improve the efficiency of the unit's operation and the quality of its examinations, this introduction also has its purpose, goals and objectives.

The introduction of a management system has the purpose of guaranteeing high quality of measurements, tests and analyses, thereby ensuring objective and reliable results; unconditional observance of the requirements imposed by regulations (standards), and of investigative techniques, as well as of the rules for the use of measuring devices and test equipment; creating the required environment for examinations; the appropriate level of the personnel competence; prompt fulfilment of the customers' requests for examinations at minimum costs; carrying out continuous self-analysis (audit of in-house activities), as well as being personal responsible for the quality of the work performed.

The key goals in the policy of implementing the management system include: maximum satisfaction, within one's competence, of customers' needs with the quality of laboratory services and precise discharge of all obligations before the customers; stable quality; ensuring the customer's appropriate confidence in quality; confidentiality conditions when performing examinations; objectivity of the outcomes, validity of conclusions, opinions and 
interpretations of the results; carrying out continuous self-analysis (audit of in-house activities) to achieve ongoing improvements in the in-house management system.

Introduction Functioning of the management system is supported by the following factors: availability of premises to perform examinations, of the necessary test equipment, measuring devices and other technical facilities to conduct analyses in full conformance to the statutory, methodological and technical documents; the statutory, methodological and technical documents that govern requirements on the examined items, methods of their examination, as well as requirements on the examination tools and the procedure for their application; skilled personnel, competent in the matters of staging and performing examinations, processing and reporting of outcomes, as well as comfortable psychological climate in the team.

\section{References}

1. Kofanov A. V., 2015. Specifics of expert's errors and ways to prevent them in a forensic ballistic examination. In: Forensic Science and Examinations - An inter-agency instructional research compendium. Ministry of Justice of Ukraine, KNDISE. Kyiv. Vol. 60. pp. 275-287.

2. Kofanov A. V., 2013. Certain aspects of the challenges in the training of forensic experts, their interaction with senior officials and assessment of their analyses. In: Forensic Bulletin - Academic and practical compendium. Chief editor V. Cherniei. DNDEKC, MIA of Ukraine; NAIAU. Kyiv: A to Z Printing House. No. 2 (20). pp. 107-116.

3. Kofanov A. V., 2015. Deficiencies in psychological and legal (professional) training of a forensic expert as a prerequisite for occurrences of experts' errors. In: Forensic Bulletin Academic and practical compendium. Chief editor V. Cherniei. DNDEKC, MIA of Ukraine; NAIAU. Kyiv: A to Z Printing House. No. 1 (23). pp. 72-79.

4. Kofanov A. V., 2018. Debatable nature of an expert opinion or its equivalent (past and future). In: Current issues of standardisation and accreditation of trace evidence and weapon examination - Proceedings of the inter-agency academic and practical seminar (Kyiv, 12 January 2018). KNDISE. Kyiv. pp. 30-34. 